\title{
ANIMAL WELFARE VERSUS ANIMAL ABOLITIONISM: A COMPARISON OF THE THEORIES BY PETER SINGER AND TOM REGAN AND THEIR INFLUENCE ON THE BRAZILIAN FEDERAL CONSTITUTION
}

BEM-ESTARISMO VERSUS ABOLICIONISMO ANIMAL: UMA COMPARAÇÃO DAS TEORIAS DE PETER SINGER E TOM REGAN E SUA INFLUENCIA NA CONSTITUIÇÃO FEDERAL BRASILEIRA

\author{
Amanda Formisano Paccagnella \\ Patricia Borba Marchetto
}

\begin{abstract}
With the emergence of environmental concerns and the awakening regarding animal treatment issues, the anthropocentric paradigm has begun to shift, causing many countries to review their position on the legal status of animals. Within the movement for animals, there are two mainly followed philosophical theories: the animal welfare perspective, which has Peter Singer as its leading author, and the animal rights theory, likewise known as the abolitionist movement, with Tom Regan as its central theorist. Utilizing the method of comparative analysis, this article seeks to analyze each author's thought process and compare theories, contrasting each viewpoint's moral and philosophical foundations and which principle each author has determined as most fundamental. The main differences between them will also be compared, as well as their conclusions and effects on society, with a particular focus on their influences on the Brazilian Federal Constitution of 1988.
\end{abstract}

Keywords: Animal welfare. Animal rights. Animal use abolitionism. Peter Singer. Tom Regan. Brazilian Federal Constitution of 1988. 


\section{RESUMO}

Com o surgimento de preocupações ambientais e o crescimento da consciência quanto às questões de tratamento dos animais, o paradigma antropocêntrico começou a mudar, causando a revisão da posição legal nesta questão por muitos países. Dentro do movimento pelos animais, existem duas teorias filosóficas principais: o bem estarismo, com Peter Singer como seu autor principal, e a teoria dos direitos dos animais, também conhecida como movimento abolicionista, com Tom Regan como seu principal teórico. Através do método comparativo, este artigo busca analisar e comparar as teorias por ambos os autores, contrastando as bases filosóficas de cada uma, os princípios em que se fundamentam e suas principais diferenças, comparando também suas conclusões e efeitos na sociedade, especialmente no que tange às suas influências na Constituição Federal Brasileira de 1988.

Palavras-chave: Bem estarismo animal. Direitos dos animais. Abolicionismo animal. Peter Singer. Tom Regan. Constituição Federal Brasileira de 1988.

\section{INTRODUCTION}

For centuries, the anthropocentric paradigm has prevailed among philosophers and scientists; however, in the most recent years, due to environmental issues and resource depletion, a paradigm shift has taken place, blurring the lines between anthropocentrism and biocentrism.

With this new viewpoint, the issue of animal treatment and animal use has become a major topic, with the well-being of animals as a focal point of concern. Many western countries have absorbed and integrated animal welfare principles into their legislation, regulating and even barring several activities considered to be cruel.

Such advancement hasn't been enough for a particular social group: the animal abolitionists. The abolitionist movement consists on an opposition to all practices of animal use by humans, declaring that nonhuman animals have rights, such as a right to life, to freedom and to not be harmed.

This perspective, also associated with the vegan movement, has been gaining strength, causing many nations to rethink their position 
regarding the legal status of nonhuman animals. Some countries that no longer classify animals as mere property are Austria, Germany and Switzerland, categorizing them in a middle position between objects and rights holders.

This article seeks to analyze the two main theories regarding the treatment of animals: Peter Singer's theory, which advocates for animal welfare, utilitarianism and the principle of equality, and Tom Regan's theory, which campaigns for the recognition of animal rights, given their inherent value.

In order to achieve that goal, this article will compare which classical theory was utilized as a basis by each author and which principles each author has declared as defining for their theories; their conclusions will also be contrasted, discussing their effects on society and determining how each of them has influenced Brazil's Federal Constitution.

\section{PETER SINGER'S ETHICAL PRINCIPLE OF EQUAL CONSIDERATION OF THE INTERESTS OF ANIMALS}

Peter Singer is an Australian moral philosopher whose book "Animal Liberation" pioneered in discussing ethics applied to animals and in arguing in favor of vegetarianism, and his body of work is considered to be the philosophical foundation of the Animal Liberation movement.

Singer 1975/2002, p. 6) also popularized the term speciesism, initially coined by Richard Ryder, and described it as "a prejudice or attitude of bias in favor of the interests of members of one's own species and against those of members of other species".

In order to further explain how speciesism came to be, Singer offers a historical background on the philosophical views which helped solidify the idea that the human species is the only one whose interests need to be considered.

Singer (1975/2002, p. 186) explains that western attitudes toward animals have roots in Judaism and Greek antiquity, which unite in Christianity, a religion founded and widespread during the Roman Empire. 
It was only with Christianity that the idea of human uniqueness was solidified; as Singer (1975/2002, p. 191) points out, “Christianity spread the idea that every human life - and only human life - is sacred. Even the newborn infant and the fetus in the womb have immortal souls, and so their lives are as sacred as those of adults".

Another period in time which helped consolidate speciesism was the Renaissance, with the rise of humanism and the placing of humans in the center of the universe. Singer (1975/2002, p. 198) explains that "Renaissance humanists emphasized the uniqueness of human beings, their free will, their potential, and their dignity; and they contrasted all this with the limited nature of the 'lower' animals".

During the Renaissance, René Descartes' philosophy proved to be one of the most damaging to the treatment of animals, resulting in the idea that animals were mere machines. Descartes was the one who originated a reasoning that subsists until present day: that only human beings have souls, and therefore, only human beings are conscious (SINGER, 1975/2002).

With the Enlightenment, Descartes' views began to be questioned. Particularly, Jeremy Bentham, in 1780, proposed that animals' interests be considered and that animal suffering be prevented and managed.

Jeremy Bentham was the founder of the 19th century school of Utilitarianism, and his work was utilized as a foundation for Peter Singer's reasoning regarding the treatment of animals.

Jeremy Bentham (1780/1907, p. 143) describes animals as agents which can be "affected by man's actions and are capable of happiness", although wrongly downgraded into the class of things. The author makes a point that eating animals is justifiable, since human beings are benefited and animals are never in a worse situation, for their death is speedier and less painful in human hands than it would be in nature.

Bentham (1780/1907, p. 143) also describes animals' lack of "longprotracted anticipations of future misery" as an important difference between human beings and animals, making it possible to maintain the idea of superiority of the human species and the habit of killing animals for food. 
However, Bentham (1780/1907, p. 144) asserts there is no reason why the human species should be allowed to torment animals and cause them suffering, drawing parallels between human slavery and animal slavery, asserting that "the day may come when the non-human part of the animal creation will acquire the rights that never could have been withheld from them except by the hand of tyranny". This reasoning led to a very famous quote by Bentham (1780/1907, p. 145): "the question is not Can they reason? or Can they talk? but Can they suffer?".

Peter Singer (1975/2002, p. 7) also determines the lack of suffering as the main rule to be followed regarding animals.

Singer's preferred school of thought is Utilitarianism, which was founded by Bentham and constitutes an ethical philosophy described as "the view that the morally right action is the action that produces the most good" (STANFORD..., 2017); in other words, every individual's interests are to be considered in order to maximize the overall good. It is important to note that this view has been criticized for allowing violent actions to be considered morally correct as long as violence constitutes the desire of the majority of individuals.

In "Animal Liberation", Singer (1975/2002, p. 21) defends the idea that good consists in the option that furthers the interests and preferences of the maximum number of beings who have preferences; and if all sentient animals have preferences, then all should be considered.

The main point of Singer's theory rests on the ethical principle of equal consideration of the interests of animals. For the author, "it is an implication of this principle that our concern for others and our readiness to consider their interests ought not to depend on what they are like or on what abilities they may possess" (SINGER, 1975/2002, p. 2); in other words, the consideration of interests should to be extended to all sentient beings, regardless of their differences.

In order to determine which beings possess interests and which don't, Singer (1975/2002, p. 7) borrows from Bentham's theory and proposes the criteria of capacity for suffering, or, as more commonly named, sentience, which the author defines as the capacity to suffer and/ or experience enjoyment. Enlightening the matter, Singer (1975/2002, p. 9) explains: 
The capacity for suffering and enjoyment is a pre-requisite for having interests at all, a condition that must be satisfied before we can speak of interests in a meaningful way. [...] No matter what the nature of the being, the principle of equality requires that its suffering be counted equally with the like suffering of any other being. [...] So the limit of sentience [...] is the only defensible boundary of concern for the interests of others.

Singer (1975/2002, p. 18) also acknowledges a crucial difference between human beings and animals: the ability to think forward and plan/ visualize a future. Because of this human ability, it would be wrong to kill a human being. In that sense, the author deems most human lives more valuable than those of nonhuman animals. However, the same reasoning makes it possible for some nonhuman animals' lives to be more valuable than some human lives, for instance, those of severely mentally disabled human beings; and Singer (1975/2002, p. 19) legitimately defends this position, deeming it "not arbitrary".

Singer's reasoning utilizes mental capacities and the ability to suffer to determine which individual's life is more or less valuable. In this sense, he campaigns for vegetarianism in light of the extreme suffering animals are put through (SINGER, 1975/2002).

Considering that the use of animals for food is virtually impossible to achieve without causing animals some harm or suffering, especially considering today's demand, Singer advocates for vegetarianism. However, for an act of killing to be considered morally wrong, the victim must have a preference to go on living, and in that sense only the killing of moral agents would be considered immoral (SINGER, 1975/2002).

It is important to point out that everything Singer applies to animals is also applied to humans, therefore escaping any speciesist reasoning. Therefore, for the author, it is possible for a human life to be more valuable than a nonhuman life; also, for a nonhuman life to be more valuable than a human one; and finally, for some human lives to be more valuable than others (SINGER, 1975/2002).

Singer (1975/2002, p. 247) concludes his theory by pointing out that humans have the power to continue to impose tyranny onto animals, "proving that morality counts for nothing when it clashes with 
self-interest", or to exercise genuine altruism by recognizing the moral indefensibility of the current system and liberating all animals.

\section{TOM REGAN'S RIGHTS AND INHERENT VALUE POSITION}

Tom Regan was an American moral philosopher whose theory, "The Animal Rights View", became the primary viewpoint of the animal abolitionism movement (popularly known as the Vegan movement). His books "The Case for Animal Rights" and "Empty Cages" caused a revolution in activists' way of thinking, prompting many to crossover from a welfarist position into an abolitionist position.

In his analysis of the problems regarding the treatment of animals, Regan first analyzes theories from select authors, separating philosophical views into "indirect duty views" and "direct duty views".

\section{INDIRECT DUTY VIEWS}

Indirect duty views propose that human beings have no direct duties to animals, but only duties involving animals; in other words, if an act of animal cruelty was committed, it would be reprehensible for the potential damage it would cause to humans, and not to the animal (REGAN, 2004b).

According to the author, there are two types of subjects within indirect duty views: moral agents and moral patients. Regan (2004b, p. 151) further explains this differentiation by stating that moral agents have more sophisticated abilities, "including in particular the ability to bring impartial moral principles to bear on the determination of what, all considered, morally ought to be done". In contrast, moral patients lack those abilities, and cannot be morally accountable for their actions. Regan (2004b, p. 151) states that "Moral patients, in a word, cannot do what is right, nor can they do what is wrong".

In that sense, an indirect duty view determines that only moral agents are members of the community, thus only their interests and rights should be taken into account; Regan (2004b, p. 154) explains that following such reasoning would mean that "moral patients, even 
paradigm moral patients (children and the mentally enfeebled) are of no direct moral significance".

As an example of an indirect duty view, Regan (2004b, p. 155) mentions Immanuel Kant's philosophy.

Kant (1785/2012) determined an obligation to always treat humanity as an end, never as a means, and defended that only moral agents should be considered ends in themselves; in other words, only moral agents possessed independent value and should never be treated merely as a means to an end. As Kant (1785/2012, p. 212) remarks about animals, "if they are irrational beings, [they have] only a relative value as means, and are therefore called things".

Although Regan (2004b, p. 184) admires Kant's theory and agrees with some of its proposals, the author criticizes Kant's view by pointing out that Kant cannot consistently defend that all human lives exist as ends in themselves, "for since human moral patients lack the rational prerequisites for moral agency, they can have only a relative value and must, therefore, given Kant's understanding of these matters, be viewed as things".

For Regan (2004b, p. 178), viewing moral patients as a means to an end would be morally wrong, for it would exclude not only sentient, nonhuman animals which, "like relevantly similar humans, have a life of their own that fares better or worse for them, logically independently of their utility value for others", but it would also exclude some human beings who, for many reasons, might not possess the rational prerequisites for moral agency (REGAN, 2004b, p. 179).

Because it denies any direct duties towards moral patients, Regan (2004b, p. 179) points out that Kant's viewpoint has one major flaw: moral arbitrariness. The author also deems all indirect duty views as inadequate for being biased. In Regan's mind, if Kant hadn't arbitrarily selected which subjects are ends in themselves, his theory could've been successful (REGAN, 2004b). 


\section{DIRECT DUTY VIEWS}

Direct duty views recognize some direct duties to moral patients; however, they do it without speaking of moral patients' rights (REGAN, 2004b). Since Regan's theory is built upon the idea of rights, the author disagrees with such views, especially given the fact that, without the concept of rights, the wrongness of killing an individual becomes challenging to approach (REGAN, 2004b).

The author begins by criticizing classic utilitarian ideas from the likes of Jeremy Bentham and John Stuart Mill, which "hold that pleasure and pleasure alone is intrinsically good, and pain and pain alone intrinsically evil" (REGAN, 2004b, p. 200); therefore, for classic utilitarianism, the best option is the one which brings the optimal balance of pleasure over pain. Also, Regan (2004b, p. 201) explains, this view considers beings as receptacles of experiences; thus their experiences are the ones which possess value, and not the individuals themselves.

Although Regan (2004b, p. 202) salutes utilitarianism for championing the cause of animal welfare, he points out some insurmountable objections to the theory.

For instance, regarding the question of killing moral agents, utilitarianism considers the pleasures and pains of the victim; however, these experiences carry no more moral weight than others' pleasures and pains. No experience or sensation is counted more heavily than the other (REGAN, 2004b).

Regan (2004b, p. 205) makes the argument that, as long as superfluous pleasures carry the same weight as horrifying pains, this position "makes killing too easy to justify. It is not only in exceptional circumstances that killing is permissible - quite ordinary circumstances would allow it. [...]The author (REGAN, 3004b, p. 205) defends that, if such an argument were to be accepted, "the door would be open to a lot of killing of moral patients, both humans and animals, especially if this is done painlessly".

As another example of a direct duty view, Regan analyzes and criticizes Peter Singer's animal liberation theory, and this objection will be further explained in due time. 


\section{THE ANIMAL RIGHTS VIEW}

Initially, it is important to point out that Tom Regan limits his animal rights theory to mammalians, given the undeniable presence of sentience in these animals; however, he does not exclude the possibility that the same thing is true of other animals, like birds and fish (REGAN, 2004a).

Regan's theory is based on the concept of inherent value, which "involves viewing certain individuals as having value in themselves" (REGAN, 2004b, p. 235); in other words, the individuals are valuable, not their experiences, as opposed to the utilitarian-receptacle view.

Regan (2003, p. 94) also rejects the idea that individuals might have inherent value in varying degrees; to the author, if all individuals possess inherent value, all are equal in inherent value. This is justified by the impossibility of viewing inherent value as something that beings can earn or lose, or something dependent on the being's utility to others or to society (REGAN, 2003).

Up to this point, Regan's theory resonates with Kant's; however, Kant restricts inherent value to moral agents, which Regan (2004b, p. 241) deems arbitrary given the following reasons:

Morality will not tolerate the use of double standards when cases are relevantly similar. If we postulate inherent value in the case of moral agents and recognize the need to view their possession of it as being equal, then we will be rationally obliged to do the same in the case of moral patients. [...] Inherent value is thus a categorical concept. One either has it, or one does not. There are no in-betweens. Moreover, all those who have it, have it equally. It does not come in degrees.

To determine which beings have inherent value, Regan (2004b, p. 242) proposes the subjects-of-a-life criterion. Subjects-of-a-life are those who are not only alive and conscious, but also possess desires, perception, memory, a sense of the future and an emotional and psychological life which "fares well or ill for them" (REGAN, 2004b, p. 243).

After explaining the concept of inherent value, Regan (2004b, p. 248) presents his interpretation of the formal principle of justice, the respect principle: "we are to treat those individuals who have inherent 
value in ways that respect their inherent value. [...] It requires respectful treatment of all who satisfy the subject-of-a-life criterion". And according to Regan (2004b, p. 261), there is no rational, nonarbitrary way to avoid this principle.

This reasoning makes it possible to consider the existence of rights.

First of all, Regan (2004b, p. 268) makes a distinction between moral and legal rights. Legal rights are those determined by law, created by society, and thus faced with great variation; on the other hand, moral rights are universal, equal and do not arise from societal creation. One might "create legal rights that accord with or protect moral rights, but that is not the same as creating these moral rights in the first place" (REGAN, 2004b, p. 268).

After establishing this line of thought, Regan (2004b, p. 279) defends that moral patients possess moral rights, since "the validity of the claim to respectful treatment, and thus the case for recognition of the right to such treatment, cannot be any stronger or weaker in the case of moral patients than it is in the case of moral agents". In that sense, animals, as moral patients, would have only basic rights: the moral rights. Legal rights, such as the right to vote, would not apply to animals.

Regan (2004b) finalizes his theory by explaining that the rights of moral patients can be overridden based on a reasoning analogous to that applied to human beings, such as circumstances of self-defense and strict necessity.

The author defends the abolition of animal use and states that vegetarianism is obligatory, since the act of using an animal doesn't treat him or her as an end in himself or herself, and does not, by a plethora of arguments which will be explained in the next section of this article, constitute a circumstance in which their moral rights can be overridden (REGAN, 2004b). 


\section{A COMPARISON OF THE PHILOSOPHIES BY REGAN AND SINGER: DIFFERENCES AND SIMILARITIES}

Peter Singer and Tom Regan converge in many points. Despite the fundamental differences in their reasoning, they reach similar - or even equivalent - conclusions many times.

For example, in regards to animal experimentation, although both authors reach similar conclusions, their reasoning is crucially different. For Singer (1985), it is not possible to say that animals have the right not to be experimented on, but, based on an utilitarian logic considering the maximum benefit, the final result would be the same, since "the suffering animals would be spared would be immense; the benefits lost at best uncertain; and the incentive thus provided for the speedy development of alternative means of conducting research, the most powerful imaginable".

In this same matter, Regan (SINGER, 1985), defends that it would be categorically wrong "coercively to put an animal at risk of harm, when the animal would not otherwise run this risk, so that others might benefit; and it is wrong to do this in a scientific or in any other context", since it would reduce the animal to the status of a mere thing. Different thought processes; however, seem to lead to very similar conclusions.

Both authors elaborate on the cultural strength of the idea that it is morally right for animals to be used and/or killed in benefit of humans, citing, for instance, the difference of treatment between dogs and cows, the invisibility of the matter and the role played by the media in maintaining the status quo (SINGER, 1975/2002; REGAN, 2004a).

Psychologist Dr. Melanie Joy, in the book "Why We Love Dogs, Eat Pigs and Wear Cows: An Introduction to Carnism", coined the term "carnism" to define the invisible belief system that perpetuates animal exploitation for food. Joy (2014) claims it is a violent ideology, since it depends on violent practices in order to be maintained. Essentially, Regan and Singer describe and criticize the same system (SINGER, 1975/2002; REGAN, 2004a).

Another point in which both Regan and Singer agree is the proven sentience of animals, especially mammals. In order to defend this, both employ ample research in areas such as behavioral science, neuroscience, 
and also reference psychological, physiological and anatomical similarities (SINGER, 1975/2002; REGAN, 2004a).

Regarding "speciesism", both authors stand by its existence, and both also attach human treatment concerns to animal treatment concerns (SINGER, 1975/2002; REGAN, 2004b). In fact, both theories are complex, complete moral philosophy theories, applicable to humans and nonhumans; nevertheless, as it turns out, their most controversial inference is for the inclusion of animals into society's moral sphere of consideration.

Both authors also defend the vegetarian lifestyle and stand by the possibility of living without any types of products derived from animals, with Singer (1975/2002, p. 244) maintaining that "a vegetarian can expect to be at least as healthy as one who eats meat", if not more.

Regan and Singer agree on these topics and more. However, there are substantial differences in their reasoning and in the ultimate inference of each theory.

One of Regan's (2004b) main concerns regarding Singer's animal liberation theory rests on its view that, in order for it be wrong to kill an individual, this individual must possess a conscious preference to go on living. Regan (2004b, p. 207) differs, adding that "by making this desire a necessary condition Singer fails to account for why we have a direct prima facie duty not to harm, by killing, animals and those human moral patients like these animals in the relevant respects". In that sense, Regan (2004b, p. 207) defends that it cannot be demanded that individuals be aware of their own mortality in order for it to be considered that they would prefer to go on living, since "it is extremely doubtful that the moral patients at issue have the intellectual wherewithal to conceive of their own death or to make the kind of comparative judgment Singer's view requires".

In that sense, Regan (2004b, p. 207) deems Singer's (1975/2002) theory arbitrary. However, the most critical difference in both theories is that Regan speaks of rights, whereas Singer does not, mentioning only a principle of equality (SINGER, 1975/2002; REGAN, 2004a).

In response to a critic's concern that in "Animal Liberation" there is a lack of analysis on the nature of rights, Singer (1975/2002, p. 219) 
stated that this fact should not come as a surprise, since he does not attribute rights to animals:

I have little to say about rights because rights are not important to my argument. My argument is based on the principle of equality, which I do have quite a lot to say about. My basic moral position [...] is utilitarian. [...] I think that the only "right" I ever attribute to animals is the "right" to equal consideration of interests, and anything that is expressed by talking of such a right could equally well be expressed by the assertion that animals' interests ought to be given equal consideration with the like interests of humans.

Ultimately, it is possible to point out the main difference between Peter Singer and Tom Regan: the first one defends a welfarist position, daring not speak of rights but only of equal consideration of preferences; the second one defends an abolitionist position, claiming that mammalian animals have inherent value and are subjects-of-a-life, and therefore possess moral rights (SINGER, 1975/2002; REGAN, 2004a).

This greatly important differentiation is what indicates the distinction of social movements each author supports: Peter Singer is deemed the founder of the Animal Liberation movement, while Tom Regan's theory is considered to be the fundamental viewpoint of the Animal Rights movement.

The Animal Liberation movement speaks of welfare, ridding animals of all types of suffering inflicted by the human race; the Animal Rights movement demands the abolition of animal slavery, defending that nonhuman animals possess inherent value and a life of their own, thus the immorality in claiming ownership of them.

\section{THE INFLUENCE OF THE ANIMAL MOVEMENT ON THE BRAZILIAN FEDERAL CONSTITUTION}

Brazil has had six Federal Constitutions since its independence. Before the advent of the current Constitution, approved in 1988, environmental concerns were legally contemplated only in matters related to health protection and economy regulation (ANTUNES, 2014, 
p. 63). It was only after its arrival that a structural shift took place: the environment was constitutionalized based on new, more holistic mandates, speckled with biocentric and even ecocentric components, giving origin to a new ethical and legal paradigm (BENJAMIN, 2008, p. 66).

Article 225 of Brazil's Federal Constitution (1988) composes its Title VIII, Chapter VI, named "Regarding the Environment”. It determines, in its text, that "All have the right to an ecologically balanced environment" and imposes its defense and protection upon the government and present and future generations. In its paragraphs, article 225 recognizes the environment's intrinsic value and establishes a system with singular principles and instruments, created solely for the purpose of safeguarding it, thus assigning it value "on an ethical basis, explicitly and implicitly, with a combination of arguments based on extended anthropocentrism (given the concern with future generations), biocentrism and even ecocentrism" (BENJAMIN, 2008, p. 85).

The language utilized by the constitutional text, specifically the word "all", has been a major topic of discussion by scholars. It is the position of the majority that the word "all" refers only to human beings; in that sense, Antunes (2014, p. 66) deems irrational and reckless the interpretation that it would refer to all living beings, since the national legal system is entirely centered around the human individual.

However, many authors defend the possibility of a paradigm shift in the future, resulting in the inclusion of nonhuman animals into the concept of "all". Herman Benjamin (2008, p. 106) points out that, currently, the word "all" does not seem to include nonhuman animals, since the same formulation is utilized in other parts of the Constitution, such as the right to education, meaning only human beings. In spite of that, the author calls attention to the fact that "since the interpretation of the norm reflects a lot of what is obtained from cultural reality, which is the incubator to our ethical values, maybe in the future nonhuman animals will be contemplated by article 225's concept of "all", in a broader, less solitary category than only human beings".

In fact, a minor group defends the inclusion of animals in the constitutional concept; for example, Trajano (2014, p. 56) explains that, if a post humanist reasoning is applied to the interpretive process, the 
inclusion of nonhuman animals in the Constitution's concept of "all" has already taken place.

Another topic of discussion particular to the subject of nonhuman animals can be located in article 225, paragraph one, subsection seven of the current Brazilian Constitution (1988), which determines the government's obligation to "protect the fauna and the flora, with prohibition, in the manner prescribed by law, of all practices which represent a risk to their ecological function, cause the extinction of species or subject animals to cruelty".

During the period in which the constituent assembly took place, in the years of 1987 and 1988, activists raised the issue of the interests of nonhuman animals through the subcommittee of health, insurance and environment. The result was an unprecedented, ample process of discussion on the matter (TRAJANO, 2014, p. 47).

According to Trajano (2014, p. 48), in this scenario, it was palpable that the battle for animal protection was related to man's social and economic interests, whether regarding research and experimentation, or agriculture and food systems, and at the same time propelled mostly by the idea of indirect duty views regarding animal protection. However, after the approval of the 1988 Federal Constitution, environmentalist constituent congressman Fábio Feldmann recognized that one of the constituent's goals was to keep an open constitutional text, in order to enable further debates such as the existence of animal rights (TRAJANO, 2014, p. 49).

The existence of biocentric components in the Constitution, certainly influenced by Peter Singer and Tom Regan's theories on animal consideration and animal rights, is noticeable, given that the Brazilian constituent did not only worry about protecting animals due to their ecological function or economic utility, but also by virtue of an awareness towards sentient life, whether it be human or nonhuman (BENJAMIN, 2008, p. 143).

Regarding the constitutional mandate of animal cruelty prohibition, it is a direct reflection of animal sentience and capability to feel pain. As previously explained, Peter Singer's theory is the one responsible for the idea of determining which being has preferences and which does not 
based on the existence of sentience. On the other hand, Trajano (2014, p. 55), a firm supporter of Tom Regan's animal rights view, defends that the Brazilian Constitution has distinguished itself from others by recognizing the existence of inherent value in other nonhuman forms of life, even protecting them from human action in itself, signaling the end of a merely instrumental view of nonhuman animal life. This interpretation continues to gain growing support, borrowing from Tom Regan's animal rights view and concept of inherent value, with some even defending that, through the constitutional prohibition of animal cruelty, animals have been categorized as rights holders.

It is Trajano's (2014, p. 49) belief that the Brazilian constituent has opened doors to the post humanization of the Constitution by updating it with ideals which go beyond human categorization, recognizing an inherent value to all nonhuman animals and allowing, through the constitutional text, an interpretation that contemplates animal dignity.

\section{CONCLUSIONS}

Within the animal cause, there are several theories looking to explain why animals should not be subjected to suffering and harmful practices, and Peter Singer and Tom Regan are the creators of two central viewpoints on the topic.

Peter Singer defends the principle of equal consideration of the interests of animals, given the fact that they possess interests and preferences which should be considered. Singer utilizes the criterion of sentience in order to determine which being has preferences and which does not.

Tom Regan's animal rights theory, on the other hand, argues that animals have inherent value when they are subjects-of-a-life; for that reason, they possess moral rights, especially the right to not be treated as a means to an end and to be included in the principle of respect. The author bases his view on Immanuel Kant's theory, with the difference that the animal rights theory doesn't restrict rights to moral agents, but extends them to moral patients. 
The prevalent difference between both theories is crucial: whereas Singer speaks of an Animal Liberation movement, Regan speaks of an Animal Rights movement. While Singer advocates for animal welfare, Regan offers an abolitionist approach. While Singer mentions only "preferences", Regan employs the term "rights".

These theories' influence around the world has been substantial, with many countries changing their laws in order to accommodate new ideals derived from them. Specifically, in the case of Brazil, the Federal Constitution has included a prohibition of animal cruelty, thus considering nonhuman animals' capability of suffering and, therefore, sentience. Peter Singer can be recognized by championing that criterion.

On the other hand, Tom Regan's animal rights theory continues to grow, and has impacted the Brazilian Constitution especially when it comes to the interpretation of the word "all" regarding the right to an ecologically balanced environment, making it possible for the argument of animals as rights holders to be made.

If the continuance of the animal rights debate was or wasn't the exact intention of the constituent assembly, it is not possible to determine with absolute certainty; however, the important point is that, even if it was not formally intended as such, contemporary cultural, social and ethical values are what will determine the interpretation of the letter of the law, making it possible for nonhuman animals to be more and more considered, and eventually included into the rights holders category.

\section{REFERENCES}

ANTUNES, Paulo de Bessa. Direito Ambiental. $16^{\text {th }}$ edition. Sao Paulo: Atlas, 2014.

BENJAMIN, Antônio Herman. Constitucionalização do ambiente e ecologização da constituição brasileira. In: CANOTILHO, J.J. Gomes; LEITE, José Rubens Morato (org.). Direito constitucional ambiental brasileiro. Sao Paulo: Saraiva, 2008.

BENTHAM, JEREMY. An introduction to the principles of morals and legislation. New Edition, Oxford, 1780/1907. 
JOY, MELANIE. Por que amamos cachorros, comemos porcos e vestimos vacas. Cultrix, $1^{\text {st }}$ edition, Sao Paulo, 2014.

KANT, IMMANUEL. The groundwork of the metaphysics of morals. Cambridge University Press, Cambridge, 1785/2012.

REGAN, TOM. Animal rights, human wrongs. Rowman \& Littlefield Publishers, Maryland, 2003.

REGAN, TOM. Empty cages. Rowman \& Littlefield Publishers, Maryland, 2004a.

REGAN, TOM: The Case for Animal Rights. University of California Press, Los Angeles, 2004b.

SINGER, PETER. Animal liberation: the definitive classic of the animal movement. HarperCollins Publishers, New York, 1975/1975/2002.

SINGER, Peter; reply to REGAN, Tom. The dog in the lifeboat: an exchange. The New York Review of Books. April 25, 1985 issue. Available in:

https://www.nybooks.com/articles/1985/04/25/the-dog-in-the-lifeboat-anexchange/. Accessed: Dec 19, 2019.

STANFORD ENCYCLOPEDIA OF PHILOSOPHY, The History of Utilitarianism, available in https://plato.stanford.edu/entries/utilitarianism-history/. Accessed Wed Jul 19, 2017.

TRAJANO, TAGORE: Direito animal e ensino jurídico: formação e autonomia de um saber pós-humanista. Thesis (Doctorate Law Program) - Federal University of Bahia. Salvador, 2014.

Enviado em: 8-9-2018

Recebido em: 19-12-2019 


\section{Amanda Formisano Paccagnella}

Mestranda em Direito pela Faculdade de Ciências Humanas e Sociais - UNESP. E-mail: amanda.paccagnella@gmail.com

\section{Patricia Borba Marchetto}

Doutora em Direito pela Universidad de Barcelona (2001), título reconhecido pela Faculdade de Direito da USP; professora na graduação e pós graduação da Universidade Estadual Paulista Júlio de Mesquita Filho (UNESP). E-mail: patricia. marchetto@unesp.br

UNESP - Universidade Estadual Paulista "Julio de Mesquita Filho" Rua Quirino de Andrade, 215 - Centro - São Paulo/SP - CEP 01049-010 